\title{
Property Valuation Education Under Internationalization
}

\author{
Yan Xiao \\ ${ }^{1}$ Chongqing Technology and Business University, \\ Chongqing, China
}

\begin{abstract}
Foreign fund investment in China creates demand for real estate appraisal, but inevitably imposes challenges on the real estate appraisal industry in China. The majority of real estate appraisers in China are not familiar with the needs and requirements of foreign clients. The core of the problems lies in real estate education in China. This paper intends to study the current condition and the gap in real estate higher education based on questionnaire survey and interview survey. The study shows that there is still a long way to go for the Chinese real estate appraisal education to match the developed countries.
\end{abstract}

Keywords: Internationalization; Property Valuation; Education; Professional bodies

\section{Introduction}

Real estate is a very important vehicle in the investment market. The demand for real estate appraisal has increasing in various countries, including China. Against the backdrop of internationalization, the emerging real estate appraisal market in China draws concern of foreign professional service agencies. Following the opening of the Chinese banking market in December 2006, foreign banks' demand for real estate appraisal has been increasing yearly. It does not take long before major real estate consulting firms like Hong Kong DTZ (DTZ), Jones Lang LaSalle (JLL) and CB Richard Ellis (CBRE), etc., set up appraisal branches in Shanghai, Beijing and other big cities.

However, compared with real estate appraisers in developed countries, Chinese appraisers are less competitive and can barely undertake real estate appraisal jobs from international clients. This may be due to the capability limitation of domestic appraisers, including low proficiency in English that restrains them from writing appraisal reports that are understood by foreign customers. It may also be partly due to the distrust attitude of foreign banks and investors towards domestic appraisal companies.

It can be seen that on the one hand, China faces heavy demand for appraisal business and professionals as the result of increasing foreign investment in real estate; on the other hand, few local appraisal companies and appraisers are awarded appraisal business by foreign investors. The dilemma raises two major questions about China's real estate appraisal education and training. What qualities and abilities do international appraisers possess? How can China educate and train internationally qualified real estate appraisers?

There has been little research in Chinese real estate (appraisal) education. There is even less discussing about the challenges to the real estate appraisal education in China in the context of internationalization. This paper intends to fill the gap by providing an analysis of the current situation and problems of real estate appraisal education and training in China.

\section{Current real estate appraisal education in China}

In China, the various disciplines of higher education are governed by the Ministry of Education (MOE). The first real estate management program emerged in the 1980s in some vocational colleges, and subsequently became a formal four-year program listed in the catalogue of undergraduate subjects (Discipline Code 1909) in 1993. By 1998, 114 universities offered real estate management undergraduate programs (Wang \& Huang). There had been two major revisions of undergraduate catalogue and subject directory. The third revision of the document was conducted and implemented in 1998, which replaced real estate management subject with engineering management in the catalogue. In other words, real estate education was officially scrapped from 1998.

The fourth revision the catalogue was conducted and complemented in September 2012, permitting real estate development and management undergraduate program to be offered as a new program. However, real estate appraisal never appears as an independent undergraduate program despite the fact that there is already a three-year real estate management and appraisal program in some higher vocational colleges for many years. Nevertheless, the formal re-admission of real estate program in the official catalogue is certainly a big step forward in real estate higher education.

According to the online university enrolment system website, before the catalogue revision in 2012, there were about 1,200 universities and colleges in China. Among them, only 40 universities offered real estate undergraduate programs, accounting for $3.33 \%$ of the total. 


\section{Problems and difficulties of real estate valuation education in China}

In order to find out the current problems and difficulties in higher-level real estate education in China, an electronic survey of educators and practitioners in China was conducted from March 2014 to March 2015. This survey received 379 responses; including 103 responses from the higher education sector $(27 \%)$ and 276 from the business sector (appraisal institutions 20\%, financial institutions $11 \%$, real estate developers $11 \%$, builders $6 \%$ and consultant companies $20 \%$ ) and government sector (4.5\%).

All respondents were randomly picked from universities and the real estate industry in Shanghai, Beijing and Chongqing, which are major cities in China. These big cities were chosen on the assumption that they could provide an acceptable profile of the real estate education and industry in China. There were 22 questions in the questionnaire, in which four questions were about the background information of the respondents. The other eighteen questions were about property valuation education.

After the questionnaires were collected, statistical analysis was made by using MS EXCEL. The feedback captured some significant views, reflecting the current status quo about real estate education as well as providing a meaningful reference for education and business sector.

\subsection{Lack of real estate academics}

The survey shows that about $43 \%$ of the respondents from universities hold a doctor's degree, while this number is much less lower in the private sectors such as appraisal companies and financial institutions. The survey result also shows over $66 \%$ of the respondents think that there is a shortage of academics, while $33 \%$ of them think there is a balanced supply. It affirms there is a big gap and unbalance in the demand and supply of academics. Universities' high expectation of academics' education qualification is one of the reasons of the shortage of academics, which causes a big gap and unbalance in the demand and supply of academics.

\subsection{Academics lack of practical experience}

The survey shows that about $58 \%$ of the respondents believe the majority of real estate academics have no practical experiences, whilst about $22 \%$ of them believe that only a few academics have no practical experiences. The remaining $20 \%$ of the respondents have no idea. It is desirable that real estate teaching staff should have practical industry experience. In some countries, real estate academics are expected to have years of industry experience and/or possess membership of a professional body. This finding is in line with the result of an earlier survey by Wang \& Huang that only around $10 \%$ of the real estate academics in China have industry experience or real estate related qualification certificate.

\subsection{Insufficient research funding}

Like other countries, research output is very important for university ranking in China. Scientific research is the focus of many Chinese universities; and academics are encouraged to conduct research that would boost the scientific research reward. Since real estate is never a mainstream discipline in China, it receives little support from funding authorities and research in this area is limited.

This phenomenon is reflected in current survey result. Nearly $50 \%$ of the respondents believe the level of real estate research is relatively lower than that of other fields and only about $18 \%$ think they are at the same level. None of them think that the real estate research level is higher than that of the other fields.

\subsection{Separation of real estate appraisal education and professional appraisal institute}

Professional appraisal associations and higher education institutions have close cooperation and frequent communication in other countries. For example, the Australian Property Institute (API) and the Royal Institution of Chartered Surveyors (RICS) have accreditation and partnership arrangements with universities to ensure property graduates meeting the expectation of the industry.

In China, the China Institute of Real Estate Appraisers and Agents (CIREA) is the professional body representing property professionals, but here is no strong nexus between the academics and the professional body. The CIREA does not accredit university real estate appraisal programs and there is weak partnership with such institutions. It takes no part in developing and providing advice on education or ensuring the universities have high quality education programs.

The undesirable situation is reflected in the survey result. Over $95 \%$ of respondents to the survey consider that there should be close link between the real estate education sector and professional bodies. However, when asked about the present relationship between the real estate education sector and professional bodies, they tend to believe that there is no contact $(11 \%)$ or little contact $(64 \%)$. Only about $7 \%$ of the respondents think both parties frequently contact with each other.

\subsection{Limited industry exposure of students}

Graduates' inability to put what they have learned into practice is a common problem home and abroad, but the problem in China is more serious. Unlike other countries, most real estate programs in China only accept full-time students. Students have little opportunity to do part-time jobs, which makes it even more difficult for them to gain work experiences. 
The undesirable situation is highlighted by the survey results that $80 \%$ of the respondents think that the real estate education sector does not have contact with real estate enterprises at all. Only about $4.5 \%$ think that they do frequently contact with each other.

\subsection{Deficiency of necessary knowledge}

The survey finds out that real estate graduates are expected to have skills in property software application, financial management, property valuation, economic analysis, marketing, bidding and contract management as well as basic engineering knowledge. The top three technical capabilities that the respondents think students lack of are as follows: economic analysis, property software related computer skills and financial management, with economic analysis being the highest rated one.

Regarding soft skills, the respondents think that students should possess skills in communication, analyzing and solving problems, learning new knowledge, cooperation, innovation, executing and practicing. The top three soft skills that the respondents think students lack of include communication, analyzing and solving problems, executing and practicing capability.

\section{International requirements for real estate appraisers}

As for the question "whether property graduates in China are ready for international practice", none of the respondents think that the real estate graduates are completely ready. A majority of them (78\%) think the graduates are partially ready and $22 \%$ think they are completely unready.

Meeting full membership requirements of real estate appraiser institutes has been the benchmark for a qualified real estate appraiser in various countries and regions such as the United States, Britain, Australia, Singapore and Hong Kong, etc. Five internationally renowned professional bodies in the aforesaid countries and region are chosen for discussion in this article. They include the Royal Institute of Chartered Surveyors (RICS), the Appraisal Institute (AI), the Hong Kong Institute of Surveyors (HKIS), the Singapore Institute of Surveyors and Valuers (SISIV) and the Australian Property Institute (API).

The valuer membership requirements of the above five professional bodies include education, skills, knowledge and attitudes. To meet the valuer membership requirements of these bodies, other knowledge fields such as advanced property valuation, real estate market analysis and statutory valuation are also covered.

In general, besides basic valuation knowledge and practicing skills, valuers also need to comply with the Code of Ethics or Standards of Professional Conduct. They are also expected to possess other soft skills like effective oral and written communication, report writing, effective verbal presentation, logical analysis and reasoning ability, research ability and computer skills, etc. In a nutshell, a qualified valuer member must possess an accredited degree, appraisal work experience, have the capability of appraising and continue professional development.

\section{Recommendations for real estate appraisal education in China}

\subsection{Improve practical knowledge of teaching staff}

In China, academics that have practical real estate work experience are restricted to a small group who has close contacts with enterprises. It is needed to enhance practical knowledge of academics. According to the results of the investigation, $78 \%$ of the respondents suggest universities should provide opportunities for the academics to get practical experience. In this regard, it is suggested that property academics should be given opportunity to work in enterprises for a period of time, such as during sabbatical leave or summer vacation, to get experience. Joint research projects with enterprises are also viable ways to help academics gain practical experience.

\subsection{Strengthen practical ability of students}

In general, students are expected to possess three critical skills, i.e. estate market interpretation ability, general tasks of analysis and adequate social skills. The following measures should be tried to achieve the goal:

- About $82 \%$ of the respondents strongly suggest that students need to have more exposure to industry practitioners and internship opportunity. There should be engagement with the industry through fieldwork and work experience in the early stages of the program, so that students can learn and develop good social skills.

- In regard to professional appraisal report writing, students should be trained to report in both Chinese and English.

- Students should be required to finish some internship program or possess minimum amount of work experience before graduation.

- Strengthening cooperation and communication between universities and appraisal firms via scholarships, prizes and internships, etc. to enhance students' practical knowledge and ability.

$\bullet$

\subsection{Create a good mechanism for teaching staff and students to get industry engagement}

Based on the results of the questionnaire, $62 \%$ of the respondents think that property education should be guided by the demands of market and enterprises, whilst about $38 \%$ think that property enterprises can assist property education, but property education must follow its own rules. 
In this regard, it is suggested that there should be a longterm and stable mechanism that could provide an interactive platform for the education sector and the property industry to communicate and work together. For example, there should be relevant policy that allows academics to take one or two years' leave to work in an enterprise. Students should be encouraged and assisted to get part-time job in the industry to gain practical experience. On the other side, practitioners should be allowed to work as full-time or part-time lecturers in universities to share experience with the students and academics.

\subsection{Strengthen the cooperation and communication between the CIREA and universities}

The CIREA should learn from its overseas counterparts to enhance cooperation and communication with higher educational institutions by:

- Reviewing and revising the contents of the units of real estate programs of relevant universities according to the change and requirements of the real estate industry.

- Introducing student membership; and carrying out various activities to foster the relationship between student members and the industry.

- Developing professional training programs for real estate appraisal students to reinforce knowledge in report writing, professional ethics and risk management, etc.

- Providing scholarships and internship opportunities for real estate students, granting awards to outstanding students and giving opportunity to exchange and visit peers within the country or overseas.

\subsection{Update curriculum to meet the need of the industry}

It is recommended that universities should consult the CIREA, which has close contact with the industry and employers, before designing curriculum. In addition, real estate appraisal curriculum should also be revised periodically according to the expectation and feedback of the industry.

Apart from valuation and other essential units, universities may consider offering English report writing as an elective unit. The essence of foreign valuation standards from developed countries such as the USA, UK and Australia, etc. should also be incorporated in the study. The aim is to introduce the basic norms and requirements of appraisal report writing in English, with a view to enhancing the proficiency in writing English appraisal report that would meet the expectation and requirements of foreign clients in China.

\subsection{Carry out pilot project for real estate appraisal degree accreditation}

The survey results show that about half of the respondents hold that professional bodies should act as an intermediary between the educational institutions and the industry. Professional bodies like the RICS and API have very successful experience in cooperation with higher education institutions. Since the CIREA has very close relationship with the real estate industry, it is constructive for it to carry out a pilot project to accredit real estate appraisal degree programs in several top universities. If there are successfully outcomes, it can then gradually extend the successful experience to other universities and colleges.

In addition, through the accreditation platform, universities can also strengthen the cooperation with other international appraisal associations such as the AI, API and RICS. Students should be encouraged to obtain student membership and participate in the training programs provided by these professional bodies including valuation methods, valuation report writing, risk management, etc.

\subsection{Innovate real estate appraisal program model in higher education sector}

Universities around the world never stop innovating education programs. Chinese universities can promote real estate appraisal programs in the form of international cooperation. Some universities have already achieved great success in international cooperative education programs other than in real estate appraisal area. The possibility of running real estate appraisal programs like " $3+1$ " (three years' study in home country and finial year in foreign countries) or " $2+2$ "(two years' study in home country and last two years in foreign countries) education projects should be explored. Cross-institutional or cross-country exchanging and communication programs for teaching staff can also be implemented. China may also attempt to import real estate appraisal programs from foreign countries.

\section{Conclusion}

There is high demand for real estate appraisal services in China. However, Chinese real estate appraisers are not capable of preparing acceptable appraisal report for foreign investors. The problem is caused by the present real estate appraisal education, which cannot meet the expectation of all stakeholders. The main issues include the lack of suitably qualified real estate appraisal academics, students' inability to put theory to practice, insufficient practical content within the program and not meeting the standards of international real estate appraisal professional bodies.

In fact, Chinese universities are aware of the problems and pay close attention to international cooperation and communication. Some of the universities have been 
successful in cross-country education programs. With an increasing awareness in improving the quality of real estate appraisal program, universities and CIREA need to work closely and gradually solve the problems through exploration, cooperation and innovation. Anyway, with the transition into a full swing market economy, it is expected to see further improvement in the quality of real estate appraisal education in China.

\section{References}

[1] Australian Property Institute (API), National Education Board Operating Guidelines, 1 December 2004.

[2] Liu, H., Reviews on Chinese property education from the experiences of foreign countries, Research On Education Tsinghua University journal, Vol. 1, pp. 114-119,1999.

[3] Liu, Y., Research and practice on the model of talent cultivation of Real estate management and valuation specialty, Journal of China Economist, Vol. 5, pp. 124$125,2010$.

[4] Manning, C. \& Epley, D., Do real estate faculty teach the skills and competencies needed by corporate real estate executives? Journal of Real Estate Practice and Education, Vol. 9, No. 1, pp. 37-59,2006.

[5] Newell, G. \& Susilawati, C., Student perceptions of the quality of property education in Australia: 1994-2009, Pacific Rim Property Research Journal, Vol. 16, No. 4, pp. 400-422,2010.

[6] Page, G., Professional socialisation of valuers: what the literature and professional bodies offers, International Education Journal, ERC 2004 Special Issue, 5(5), pp. 105-116,2005.

[7] Wang, H. \& Huang, Y., Present situation of property undergraduate talents training in higher education institutions of china, Modern Enterprise Education Journal, Vol. 16, pp.160-161, 2011.

[8] Wilson K.L., Lizzio A. \& Ramsden P., The development, validation and application of the Course Experience Questionnaire, Journal of Studies in Higher Education, Vol. 22, Iss. 1, pp. 33-53,1997. 